\title{
Fighting against fuel poverty by collaborating with social services through energy advice: An innovative case from Spain
}

\author{
Iñigo Antepara*1, Frederik Claeyé ${ }^{2}$, Alex Lopez ${ }^{\dagger 3}$, Benoît Robyns ${ }^{4}$ \\ ${ }^{1}$ University of the Basque Country (UPV/EHU), Spain, Assistant Professor \\ ${ }^{2}$ ICHEC Brussels Management School, Belgium, Associate Professor \\ ${ }^{3}$ GoiEner, Spain, Volunteer \\ ${ }^{4}$ Junia, Grande Ecole d'Ingénieur, Lille, France
}

\begin{abstract}
The aim of this article is to describe the efforts against energy poverty of GoiEner, an energy cooperative in Spain, giving energy advice to the social services of two municipalities, Zarautz and Usurbil. Electricity contracts of low-income households were revised and improvements were proposed, according to the specificities of the Spanish electricity market; prioritising the regulated tariff with social bonus, then time-of-use tariff and optimising power capacity. Switching to the regulated tariff can realise savings of around $10 \%$, theoretically up to a $40 \%$ if the rest of the optimizations are included. Unexpectedly, some of the household were reluctant to change the conditions of their contracts. Training sessions were organised so that in the future this intervention could be done without the help of GoiEner. Conclusions can be drawn on how GoiEner can capture the possibilities new technologies, such as smart meters, offer.
\end{abstract}

Keywords: Energy Poverty, Energy cooperative, Energy advice, Smart meters, Tariff switching, Social innovation.

Resumen: El objetivo de este artículo es describir los esfuerzos contra la pobreza energética de GoiEner, una cooperativa energética de España, que presta asesoramiento energético a los servicios sociales de dos municipios, Zarautz y Usurbil. Se revisaron los contratos de electricidad de hogares de bajos ingresos y se propusieron mejoras, de acuerdo con las especificidades del mercado eléctrico español priorizando la tarifa regulada con bono social, luego la tarifa discriminación horaria y la optimización de la potencia contratada. El cambio a la tarifa regulada puede suponer un ahorro de alrededor del 10\%, teóricamente hasta un $40 \%$ incluyendo el resto de optimizaciones. Sin embargo, algunos hogares se mostraron reacios a cambiar las condiciones de sus contratos. Se organizaron formaciones para que en el futuro esta intervención pudiera hacerse sin ayuda. Se pueden sacar conclusiones sobre cómo GoiEner podría beneficiarse de las posibilidades que ofrecen las nuevas tecnologías, e.g. medidores inteligentes.

Palabras clave: Pobreza energética, Cooperativas de energía, Asesoramiento energético, Contadores inteligentes, Cambio suministrador, Innovación social.

EconLit keywords: B55 Social Economics, P13 Cooperative Enterprises, D18 Consumer Protection, P18 Energy • Environment, O35 Social Innovation

* Corresponding author/: Iñigo Antepara Lopez de Maturana. ALOKABIDE, S.A. Sociedad del alquiler, Dpt. Técnico inigoantepara@hotmail.com

How to cite: Antepara, Iñigo; Claeyé, Frederik; Lopez, Alex; Robyns, Benoît (2020). «Fighting against fuel poverty by collaborating with social services through energy advice: An innovative case from Spain», GIZAEKOA - Revista Vasca de Economía Social, 17, 71-96. (https://doi.org/10.1387/gizaekoa.22228).

Received: 19/03/2020; Final version: 02/04/2020.

ISSN 1698-7446 - elSSN 2444-3107 / (c) 2020 UPV/EHU 


\section{Introduction}

The energy transition approach has long been dissociated from its social aspect. UK was the first country including vulnerable consumers as a target population within the energy transition law. The Office of Gas and Electricity Markets (Ofgem) wrote a discussion paper on non-traditional business models (Jeffrey Hardy, 2015), supporting transformative change in the energy market, with a greater focus on affordability and supporting vulnerable consumers. France also included fuel poverty in the law for the energy transition, and the Observatoire National de la précarité énergétique (National observatory on energy poverty; ONPE) further argues that the fight against energy poverty is a priority area for the successful transition to the new energy regime. In November 2016, the European Commission (EC) published the "Winter Package" that presents measures with regard to the clean energy transition without putting vulnerable and energy poor consumers aside (European Commission, 2016).

This is not the case of Spain, where the Energy Transition Law was recently discussed but not including vulnerable consumers. The Basque parliament recently approved the energy sustainability law for Basque public administrations, covering all sectors of society. During the hearings before the approval many of the experts mentioned the issue of energy poverty.

The EC has stated that it does not support a single European definition of fuel poverty, although Thomson et al. (2016) demonstrate that many of other EU institutions and consultative committees are in favour of a common European definition of fuel poverty, and have been arguing for it for the last years.

Based on data from the EU Survey on Income and Living Conditions (EU SILC) an estimated 54 million European citizens (10.8\% of the EU population) were struggling to attain adequate warmth, pay their utility bills on time, and live in homes free of damp and mould in 2012 (Steve Pye and Audrey Dobbins, 2015). In France, according to the latest data from ONPE, in 2016 one in five French households are in a situation of fuel poverty with respect to at least one of the French indicators (Devalière and Bernard, 2016). In 2012, 17 per cent of Spanish households spent more than 10 per cent of their income on domestic energy. The Basque region is in a better position compared to the other regions in Spain (Tirado and Jiménez Meneses, 2016), thanks to its higher GDP per capita and regional social benefits, although the climate conditions are worse than in the South of Spain.

The question, then, is how new energy markets will make energy transition progress, without leaving vulnerable populations behind? How 
will the rights of the vulnerable be protected from the right to making profits? While we do not pertain to answer that immense societal question here, this paper does aim to provide some avenues for an equitable energy transition, embarking also the most vulnerable populations.

Drawing on the data from a collaboration with two small villages performed by GoiEner, this paper will analyse data from energy bills, used to advice best electricity tariffs to designated households. The remainder of the paper is structured as follows: this introduction is followed by an overview of the Spanish electricity system and new actors, such as the GoiEner energy cooperative. In the following section we introduce switching tariffs, as a competition improving mechanism, and briefly touch on some notions on fuel poverty policy. Then, we argue that the mixing of tariff switching and claiming social benefits drives to better advice interventions. We present the methodology and data analysis before turning to the findings and discussion thereof. The article finishes by explaining how GoiEner can improve this intervention, and some possibilities new technologies could offer if the regulation were changed.

\section{Electricity market and support for the vulnerable}

\subsection{Spanish electricity system and new actors}

Although the Spanish electricity market was liberalised in 1997, it is still organised mainly around five large electricity companies (Ooms et al., 2016). These economic policy decisions made domestic electricity prices remain regulated, and Spanish electricity prices are currently made up of two main components. One is generation costs determined in wholesale market auctions by electricity producers. The second component is regulated costs set by the Government. These include transmission and distribution costs, 'extra-peninsular' costs (i.e., subsidies to Balearic and Canary islands residents justified by higher generation costs in Spanish overseas territories) and subsidies for renewables and co-generation (Tirado and Jiménez Meneses, 2016).

This makes up the price calculated daily by Red Eléctrica de España, as Spanish Transmission System Operator, based on the energy prices per hour in the spot market and applying the average consumer profile. This price was previously set by a quarterly auction. These prices will be applied to the electricity consumption (variable energy charge-kWh consumed) of the bill. The consumer has different costs plan options, chosen between the general tariff, the time-of-use ( $\mathrm{ToU}$ ) tariff or the super-valley tariff (electric vehicle). The total of the electricity bill is completed by the inclusion of a 
fixed charge proportional to the power contracted by the user as well as the taxes established by current legislation (CNMC, 2015).

With regard to the different types of electricity contracts in Spain (CNMC, 2015), small electricity customers (below $10 \mathrm{~kW}$ ) have the right to be supplied by Reference Suppliers under the modality called "Voluntary Price for the Small Consumer" (PVPC) as developed by Royal Decree 216/2014. This category of customers can also choose a regular supplier in the open market. Another option is the ToU tariff. In October 2015, the first bills based on hourly consumption and hourly prices were issued to customers equipped with smart meters. This measure will provide a dynamic price signal to small customers and consequently, a way to implicitly participate in the market by shifting consumption to the hours of the day where energy is cheaper (CNMC, 2015).

The rise in average electricity expenses is the most significant trend. Consumers experienced a 63 per cent nominal increase in 2006-2012 versus a 26 per cent rise in the EU28. Unsurprisingly, Spain reported the sixth highest electricity price in the EU as of the end of 2012. As a result, average household annual energy expenditure went from $€ 768$ (€851 in 2008) to $€ 1,135$ per year in 2012 (Tirado and Jiménez Meneses, 2016).

Regarding new actors in the energy market, in Spain and in other Member States (MS), energy cooperatives are defined as cooperatives that are formed for the purpose of producing, selling, consuming or distributing energy or other services related to this area. Through energy cooperatives, members address their common need for affordable and reliable electricity and modern energy services as well as other related economic, social and cultural needs (ILO, 2013). They present an interesting form of social innovation in which citizens together develop completely new ways to organise the energy system driven by a sense of community and local ownership; for example, many times they opt to install renewable energies (Mengolini and Vasiljevska, 2013).

In the Spanish energy market, energy cooperatives appeared recently linked only to electricity. However, they are increasing the number of new members quickly, spreading all through the regions of Spain, and many cooperatives already exists: Som Energia, GoiEner, Nosa Enerxia, Solabria, and GoiEner being the second biggest.

GoiEner is a non-profit cooperative where all the benefits that are obtained from marketing green electricity are returned again to the cooperative, deciding how to use these profits in an assembly of members. GoiEner wants citizens to regain control over this basic needs and to make them aware of its importance, thus promoting a responsible and sustainable consumption of energy with as rational and efficient a usage as possible. At the same time, they will be able to invest in renewable 
energy projects, and this energy will be consumed by the cooperative itself, satisfying the quantity of energy required by its members. So, their activities include commercialization and generation of electricity, since transport and distribution are still regulated by the government.

GoiEner started in 2010-11 thanks to a promoting group, where all of partners were volunteers, until it become a company in December 2012. They got the New Business Ideas Award from GOIEKI (a local agency for the promotion of new projects). This award was the launch for GoiEner. It started with 32 partners. Since 2013 the partners can subscribe for a contract to get electricity from GoiEner. GoiEner avoids 'aggressive' or viral campaigns, therefore it grows in a very controlled and organic way (Ooms et al., 2016). In March 2020 there are more than 11,600 partners, managing more than 14,500 contracts (most of them in the Basque region).

Although there was large experience with cooperative enterprises in general in the Basque Country, the GoiEner initiative is innovative because it was the first energy collective. It is also an innovative solution because it searches for collaborations between GoiEner's worker members (those that get a salary from GoiEner; more than 30 in the beginning of 2020) and volunteers that work in GoiEner's project development. The members are represented in the governing board, but the most important decisions are taken at the annual general assembly. The group of volunteers, around 120 people, are members of the cooperative who wanted to help doing voluntary work (Ooms et al., 2016).

GoiEner collaborates with other institutions that share its mission, vision and values. GoiEner works together at different levels with Rescoop (European Federation for Renewable Energy Cooperatives), or REAS Euskadi (Basque network for solidarity economy), among others. Furthermore, in the area of advocacy, they have held several meetings with political representatives where they have exposed the implications of electricity reforms and its impact on the industry, society and the situation in which renewable energies are present (Ooms et al., 2016).

\subsection{Fairer bills in the energy market through switching to best tariffs and LIHs}

Switching tariffs could be a way of improving the competition in the energy market, and therefore, of achieving fairer energy bills. This is true for the UK (high switching rates of around 12\%, and high potential savings of more than 200 euros/year) or France (low potential savings, less than $5 \%$, so, low switching rates of around 40 euros/year), with selling 
prices of electricity regulated in France while this was abolished in UK long time ago. Outliers of this trend line are Germany, Latvia, and Poland because the potential savings are significant compared to the low switching rates on the one hand, and Portugal on the other with relative low potential savings compared to the tariffs switched (ACER, 2016). Despite being a low margin business, discounts are significant in many countries.

In Spain switching rates are high, more than $10 \%$, but the potential savings are only around 75 euros/year (ACER, 2016). Research has shown that consumers' expectations of potential gains were considerably lower than those available in the market, and Spanish people are particularly reluctant to trust new energy suppliers or unaware that they have a choice of energy suppliers (Crampes and Waddams, 2017). Some reasons were highlighted in a report by the National Commission on Markets and Competition (Comisión Nacional de los Mercados y la Competencia, CNMC) (2017):

- Seven out of ten Spanish households do not know whether their natural gas or electricity supply is on the regulated or open market;

$-41 \%$ also do not know what type of electricity tariff they have contracted and $24 \%$ what the contracted power is;

-Electricity suppliers make $56 \%$ of domestic customers contract the most expensive rates.

Switching tariffs, which involves assessing energy usage, choosing the best payment method and other factors such as dual fuel, customer service, green tariffs or capped rates, is a complex process best achieved through price comparison (Lorenc et al., 2013).

By the end of 2013, the Spanish Organisation of Consumers and Users (OCU) mobilised customers to form a community buying group, to increase their negotiating power, create economies of scale, and push energy providers to deliver lower costs.

Multiple municipalities in Germany, and Robin Hood Energy in the UK buy electricity and resell it at a reasonable price. The Nottingham City Council, after a series of consultations, concluded that the most effective way to tackle fuel poverty was to set up its own energy supply company to sell directly to the domestic end-user at the most affordable price possible. However, the Robin Hood model is based on the customer then staying with them over time and benefiting from a continuously competitive rate, rather than having to keep switching when their initial switch deal runs out (One Corby Policy Committee, 2016). As a consequence, on average in the East Midlands, the contracts are more than $£ 100$ cheaper (Kirk, 2017).

Some community energy initiatives also purchase a similar aim. Energy Cafés provide help for people to understand and manage their 
energy bills, but they also offer advice on energy efficiency, behavioural measures and renewable energy. Energy bills are difficult to understand for the majority of people. Particularly vulnerable people may struggle to navigate and manage their energy supply contracts so as to get a fair deal. An explicit aim of the Energy Cafés was to ensure that clients understand energy bills, how their energy consumption is billed and reported back to them, with many Energy Cafés providing actual energy price calculations for switching suppliers. Some Energy Cafés also provide services that government or energy suppliers might not, such as switching suppliers or supporting clients in energy bill disputes (Martiskainen et al., 2018). Similarly, local voluntary/community organisations facilitate energy tariff switching (Lorenc et al., 2013).

\subsection{Fuel poverty policy in Europe, and the particular case of the Spanish electricity market}

Many EU MS already have their own regulations on the issue of energy poverty, with very different fuel poverty policies. Some protect vulnerable consumers through the market in some EU countries, others use more general social policy as a completely separate instrument for such consumers. Bouzarovski (2017) states that EU energy poverty policy has been limited by the subsidiarity principle, and as such has been largely shaped by instruments related to the Single Market, even if energy efficiency and social policy-related efforts have also played a role.

MS use a combination of economic measures (to ensure prices are affordable and to assist consumers in arrears) and non-economic measures (regulation of the process for arrears and disconnection and support in finding the best tariff and increasing energy efficiency) (Bouzarovski, 2017). Energy efficiency measures are not important for this article, although a wellestablished policy of energy efficiency in housing, as in the Nordic countries and Germany enable people to live in warm homes - even while facing high energy prices (Association for the Conservation of Energy, 2013).

MS commonly employ specific protection measures for customers in remote areas, suppliers of last resort, default suppliers and social tariffs for vulnerable customers. Social policy measures to combat energy poverty typically take the form of financial assistance-social tariffs, lower tariffs of subsidies made available to vulnerable consumers, such as winter and cold weather payments for the elderly or disabled (Bouzarovski, 2017). Those financial mechanisms can be either through social welfare payments, or direct payments to specific groups e.g. the elderly, to assist with energy bills. A number of MS also have social tariffs in place, ensuring that more 
vulnerable consumers can access the most affordable energy. It has the consideration of public service obligation pursuant to Directive 2009/72/ EC (CNMC, 2015).

Different types of financial mechanisms exist. Some are received automatically, others are accessible under claim. So, some measures are paid directly as part of a social welfare package while others require consumers to be proactive (Steve Pye and Audrey Dobbins, 2015). In Spain (social policy) low-income households have to apply for the social tariff, while in UK (energy policy) special payments exist targeting different segments of population. In France (energy \& social policy mix), an energy check is being sent automatically since January 2018 to households considered as low-income according to their fiscal data. Afterwards, they have to decide which energy supplier or energy efficiency provider will be the recipient of the check. In the end, if poor people are less proactive, they may pay even more for energy bills compared to those not in poverty (Sara Davies et al., 2016).

In Spain, as in other MS, household income and domestic energy prices, especially electricity prices, are among the various factors driving the evolution of energy poverty levels. Electricity is a key component of Spain's domestic energy demand and the most costly item of the average household's energy bill (Tirado and Jiménez Meneses, 2016).

If fuel poor households are defined as households that cannot afford to keep adequately warm at reasonable cost, electrical heating can be out of consideration in many regions as electricity is not the main vector of energy used for heating. But if the following is taken into account:

1. In some other European regions electricity is the preferred source of heating (e.g. coastal regions in the south of Europe).

2. Many Spanish households still rely on electricity-based heating when the dwelling does not have a pre-installed heating system (Tirado and Jiménez Meneses, 2016). They cannot afford two different energy contracts (electricity and gas), and they choose electricity because it offers access to additional energy services (lighting, communications...).

3. Examples of Net Zero Energy Buildings (nZEB) are very scarce, and families in difficulties are sheltered in nZEBs thanks to specific social housings, but it will be like that by law in the future for the whole building stock.

If this is taken into account, it is not out of question an analysis of fuel poverty based only on electricity. Additionally, the concept of vulnerable customers was established within the old Spanish regulation so far for electricity customers, nothing similar exists for gas market. 
The 6th October 2017, the Spanish parliament approved the Royal Decree $897 / 2017$, regulating the figure of vulnerable consumers, the social bonus and other protective measures for domestic consumers of electrical energy. The main changes in the new Royal Decree, which still focuses exclusively on electricity, are as follows:

- Beneficiaries: large families, pensioners with minimum pension and vulnerable customers. They are then classified into 3 categories, according to income levels: vulnerable customer, severely vulnerable customer, and customer at risk of social exclusion (those assisted by the social services).

- Benefits: The social bonus, the difference between the last resort tariff and the PVPC, will vary between $25 \%$ and $40 \%$ (even $100 \%$ for customer at risk of social exclusion, if the social services are paying 50\%), but including consumption limits per each of the categories. As the Spanish electricity market is regulated, and only biggest retailers are designated as reference retailers, the social tariff can be only offered by those reference retailers.

- Supply interruption: 4 months after invoice issue for vulnerable customers, and no supply suspension for vulnerable customer at risk of social exclusion. But in all cases, social services have to receive a communication.

—Financing procedure: the financing of the social tariff is shared by all supply companies, according to their customers share.

In the Basque region, as in the rest of Spain, fuel poverty is an issue of general concern only since 2012, but it was not until 2014 when the Congress of Deputies, Spain's legislative branch, and some regional parliaments registered legislative action explicitly mentioning energy poverty.

\subsection{Advice interventions mixing tariff switching and claiming social benefits}

Big energy utilities usually do not support social services and / or low-income households, collaboration with social services to solve problems of low-income households is unusual. As an exception, the French EDF opened a web portal for giving support to social workers called "Pass'EDF" (Portail d'Accès aux Services Solidarité) (Antepara and Claeyé, 2016).

Many public institutions in countries all around Europe provide help to low-income households, and the social services of many municipalities have to take care of families in difficulties. When public money is used 
to support the vulnerable in fuel poverty situation, then, which is the most efficient way of using the public budget? On the one hand, without taking into account the implementation of possible energy efficiency systems, those paying taxes may ask for the lowest public budget "without putting vulnerable and energy poor consumers aside" and can demand the most efficient behaviour of the low-income households. But at the same time, focusing on energy prices, low-income households should expect the fairest tariff from the utilities. To sum up, it should be about paying the fairest energy bills with public budget: somewhere in between the right to private profits and the right to access to energy services of the vulnerable.

If we focus on the difficulties of the low-income households, sometimes they have to overcome institutional / administrative barriers (Antepara and Claeyé, 2016) such as regulatory issues and/or complexities due to the variety of stakeholders involved.

Vulnerable populations also experience the information barrier (Antepara and Claeyé, 2016) due to a lack of understanding and expertise regarding financing and benefits. The conclusions of a recent study within a Spanish project on 'Vulnerable consumers in the electricity sector', including an online survey and discussion groups (HISPACOOP, 2017), are as follows:

$-65 \%$ of elderly and disabled people claim to have a lot $(29 \%)$ or some difficulty $(36 \%)$ in understanding the electricity bill;

$-46 \%$ of vulnerable consumers consider their electricity contract to be written "in another language."

Switching energy suppliers or technology are also perceived as too complex. Vulnerable consumers would be less reluctant to switch suppliers if more information or training in new IT were provided.

Utilities use several ways of informing end users, also including lowincome households, through paper-based advice, or thanks to automatic apps or web sites. Face-to-face advice is unusual.

Interventions can be introduced to support payment of energy bills by helping to claim special funding and / or using free-market mechanisms such as switching to a cheaper energy tariff (Lorenc et al., 2013).

This paper aims to show the innovative case of an energy cooperative doing what big utilities in Spain do not do to fight against fuel poverty: an intervention based on advising best tariffs, working together with social services and low-income households, always claiming social benefits they have right to. Finally, some improvements to push the vulnerable to tariff switching are proposed. 


\section{Collaboration between GoiEner and municipal social services}

GoiEner will have to adopt the new Law of Energy Poverty in Spain. As it is a non-reference retailer, GoiEner cannot offer the social tariff (not in 2016, and not according to the draft of the new law). Unexpectedly, a survey among members of the Spanish energy cooperatives showed that consumers in difficulties can be found also within the energy cooperatives (Gabiola et al., 2016), as is the case of GoiEner. So, they will have to contact municipal social services before a cut-off, and a basic procedure is already under discussion. This is one of the motivations of this collaboration.

The social bonus, the difference between the last resort tariff and the regulated tariff was a $25 \%$ discount before the approval of new Social Tariff mechanism (only for electricity customers) (CNMC, 2015).

The access to the social tariff was not, and is not, automatic, it has to be asked by the beneficiary. Additionally, the beneficiary had to meet one of the following conditions: consumers (less than $10 \mathrm{~kW}$ ) with contracted demand lower than or equal to $3 \mathrm{~kW}$, a pensioner older than 60 years with a minimum pension, families where all members are unemployed and large families. By the end of 2014, about 2,5 million contracts were benefiting from this tariff.

Before the Royal Decree of October 2017, the financing of the social tariff was shared only by the companies that own electricity generation facilities, at that moment the retailers of reference (Gabiola et al., 2016).

GoiEner established a collaboration with the social services of two Basque municipalities, Zarautz and Usurbil, to help them with the electricity contracts of families in difficulties, designated by the social services of two municipalities. Members of energy cooperatives are a key part of the whole history, both worker-member as well as members volunteering, building a volunteer-assisted energy advisory mechanism in the choice of electricity tariffs/prices to support social services working with vulnerable households. A social worker is not an expert on energy consumption, but is the public agent with the best first-hand knowledge of the real problems faced by vulnerable households (Scarpellini et al., 2017).

A second aim is to develop the autonomy of the social services in energy advice. To do so, social services and families are trained on the issue of electricity bills. The basic idea is to start the dynamics of the intervention and afterwards it will continue alone with minimum assistance from GoiEner. In the end, the social services themselves will be capable of giving this training to their own assistants and families, closing the circle.

The novel approach of this proposal is that interventions will be innovative regarding the electricity retailing market: e.g. based on 
supporting the social services, involving groups of volunteers and even though the households under analysis who do not have a contract with the energy cooperative.

\subsection{Data analysis methodology and dataset}

The aim of this study is to present a case study of a collaboration between a small utility cooperative and the social services of two municipalities. The Spanish electricity tariff includes the terms shown in the following equation, an example on "How to calculate Spanish electricity bills" can be found in (Spanish Gov., 2015):

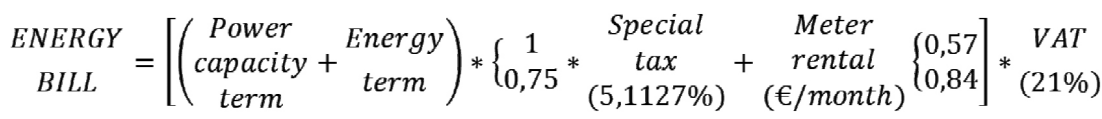

The explanation of the terms in equation (1) can be found in Table1. The margins were published by the Spanish Gov. as BOE-A-2016-12274, and the data for 2016 for those terms was published by IDAE (2016). The electricity production cost between $01 / 01 / 16$ and 31/10/16 can be calculated thanks to the Lumios tool from the Spanish Electricity Network (Red Eléctrica Española, 2017).

Table 1

The terms of the Spanish electricity tariff

\begin{tabular}{|c|c|c|c|c|}
\hline \multirow{2}{*}{$\begin{array}{c}\text { Power Capacity } \\
\text { Term }\end{array}$} & \multicolumn{3}{|c|}{ Power capacity term } & $38,043426 € / \mathrm{kW} /$ year \\
\hline & \multicolumn{3}{|c|}{ Retailing margin } & $3,113 € / \mathrm{kW} /$ year \\
\hline \multirow{9}{*}{ Energy Term } & \multirow{3}{*}{\multicolumn{2}{|c|}{$\begin{array}{c}\text { For the regulated tariff } \\
\text { (PVPC) }\end{array}$}} & Energy term & $0,044027 € / \mathrm{kWh}$ \\
\hline & & & Electricity production cost & $0,055418 € / \mathrm{kWh}$ \\
\hline & & & Variable margin & $0,001811 € / \mathrm{kWh}$ \\
\hline & \multirow{6}{*}{$\begin{array}{c}\text { For the } \\
\text { Time-of-use } \\
\text { tariff (ToU) }\end{array}$} & \multirow{3}{*}{$\begin{array}{l}\text { During } \\
\text { Peak } \\
\text { hours }\end{array}$} & Energy term & $0,062012 € / \mathrm{kWh}$ \\
\hline & & & Electricity production cost & $0,059095 € / \mathrm{kWh}$ \\
\hline & & & Variable margin & $0,001824 € / \mathrm{kWh}$ \\
\hline & & \multirow{3}{*}{$\begin{array}{l}\text { During } \\
\text { Valley } \\
\text { hours }\end{array}$} & Energy term & $0,002215 € / \mathrm{kWh}$ \\
\hline & & & Electricity production cost & $0,045447 € / \mathrm{kWh}$ \\
\hline & & & Variable margin & $0,001759 € / \mathrm{kWh}$ \\
\hline
\end{tabular}


The total of power capacity term and energy term are subject to a special tax for electricity of $5,1127 \%$. The data for 2016 were published by IDAE (2016). The rental of the meter is also subject to payment IDAE (2016):

— 0,54 €/month, for Single Phase Smart Meter without time-of-use and without tele-operation;

— $0,81 € /$ month, Single Phase Smart Meter with time-of-use and teleoperation.

Additionally, the rental of the power control switch is $0,03 € /$ month. Finally, the consumption tax VAT is $21 \%$.

The social tariff in 2016 was a discount of $25 \%$ over the Power capacity and Energy terms of the regulated tariff, so, a coefficient of 1 to 0,75 was included in the equation. The right for the social tariff is not automatic for every household, and beneficiaries can only get the social tariff if they apply for it and fulfil the conditions. The casuistic will be further discussed later.

The analysis was performed following those simple assumptions:

1. First, calculating regulated tariff (PVPC), as all the households have access to it,

2. Then, the discount due to the social tariff (the assumption is that all the households SHOULD have the social tariff),

3. Switching to the ToU tariff, and consuming $50 \%$ of the electricity during peak hours,

4. Finally, lower the power down to $3,45 \mathrm{~kW}$ only when it is over $4,6 \mathrm{~kW}$.

Not all these assumptions can be adopted in practice. For example, although the contracts analysed were from families assisted by municipal social services, not all of them are eligible for the social tariff. But the aim of this part of the collaboration was to theoretically calculate the potential savings (not the real realised ones).

\subsection{Dataset}

Data are provided by the social services of two councils, Zarautz and Usurbil. The municipalities in the Basque region can assist vulnerable families with unusual expenditures (broken domestic appliances, dental surgery...), including also energy bills. Data come from families in difficulties designated among those which receive these municipal aids for emergency cases (ayudas de emergencia social, AES), more specifically, their electricity bills. 
Zarautz is coastal town with a mild climate (550 heating degree-days). Although it is a touristic place (worldwide known as a good place for surfing) with many touristic apartments close to the beach, some families are experiencing difficulties in the surrounding neighbourhoods. Many people use electricity for heating purposes, as the heating needs are not enough to justify a gas contract with a utility.

In the inland but not far from coast, Usurbil has also a mild climate, slightly colder, but still suitable for using electricity for heating. The village is rural and not touristic.

Zarautz and Usurbil are located in the Basque province of Gipuzkoa, which had a population of 710,699 in January 2016, according to the Basque Statistics Institute (Euskal Estatistika Erakundea, EUSTAT) (2016). In the whole province, 15,039 households were benefiting from the guaranteed income (renta de garantia de ingresos, RGI) in December 2016 (Lanbide, 2016) and 7,947 households were beneficiaries of AES (personal communication with Arantza Orbegozo, in charge of the data of AES at the Basque Gov.). Data on beneficiaries being assisted by the municipal social services of Zarautz and Usurbil can be found in Table 2.

Table 2

Data on beneficiaries being assisted by the municipal social services of Zarautz and Usurbil

\begin{tabular}{lccccc}
\hline & $\begin{array}{c}\text { Population } \\
\text { (2016) }\end{array}$ & $\begin{array}{c}\text { Beneficiaries } \\
\text { of RGI in } \\
12 / 2016 \\
\text { (households) }\end{array}$ & $\begin{array}{c}\text { Beneficiaries } \\
\text { of AES } \\
\text { in 2016 } \\
\text { (households) }\end{array}$ & $\begin{array}{c}\text { AES for } \\
\text { maintenance; } \\
\text { energy bills, } \\
\text { etc. in 2016 } \\
\text { (households) }\end{array}$ & $\begin{array}{c}\text { N.o points } \\
\text { analysed }\end{array}$ \\
\hline Zarautz & 23.117 & 290 & 142 & 92 & 61 \\
Usurbil & 6.197 & 97 & 49 & 24 & 6 \\
\hline
\end{tabular}

The 61 contracts in Zarautz may be not enough for statistical purpose, and even less the 6 contracts in Usurbil. But this was not the aim of the analysis, it was more as a case study.

\subsection{Results of the analysis of the energy bills}

A description of the contracts provided by the social services of both municipalities is displayed in Table 3. 
FIGHTING AGAINST FUEL POVERTY BY COLLABORATING WITH SOCIAL SERVICES...

Table 3

Description of the contracts provided by the municipal social services of Zarautz and Usurbil

\begin{tabular}{lccrr}
\hline & $\begin{array}{c}\text { Total of } \\
\text { contracts }\end{array}$ & $\begin{array}{c}\text { Contracts with the biggest } \\
\text { retailer in the Basque } \\
\text { region }\end{array}$ & $\begin{array}{c}\text { Regulated } \\
\text { tariffs }\end{array}$ & Social tariffs \\
\hline Zarautz & 61 & 47 & 28 & 14 \\
Usurbil & 6 & 4 & 2 & 1 \\
\hline
\end{tabular}

In Zarautz, the total number of contracts is 61 , although 3 of them were not possible to be analysed because the energy bills provided were not electricity ones. 47 of the 61 contracts were with the biggest retailer in the Basque region, 28 of them with the regulated tariff (including 14 social tariffs, all the social tariffs in Zarautz) and the other 19 in the open market. The rest of the contracts are in the open market, mainly with the second biggest retailer in the Basque region (8 of the total).

In Usurbil, 4 tariffs were contracted with the biggest retailer in the Basque region, 2 of them in the regulated market (only one social tariff) and the other 2 in the open market. The remaining 2 contracts are in the open market, each of them contracted to a different company.

\section{ZARAUTZ}

From 61 contracts, in 29 cases savings can be realised by switching to the regulated tariff (all in the open market, except one which is making very good use of the ToU tariff), with an average saving of $108 € /$ year. This is a $9 \%$ of the total amount paid for the council of Zarautz to support those families, and it can always be realised, all the low-income households can switch to this tariff.

It won't be always the case of the 44 contracts without social tariff: it is not possible to say whether all of them are eligible for this tariff, and in practice they are not. But assuming all of them are elegible, the calculated average savings would reach $26 \%$. Hence, an additional average saving of $130 € /$ year could be achieved. The savings for most energy intensive households could be as high as $45 \%$, but no savings are calculated for 4 regulated contracts using the ToU tariff.

Further savings could be achieved for 50 contracts by switching to ToU tariff. Following a quite conservative criteria, supposing that $50 \%$ of the electricity consumption is done during peak hours (all of those already with the ToU tariff, 11 contracts, consume at least half of the energy 
during valley hours, 9 of them with a much better balance). This would represent additional savings of around $134 € /$ year on average for those 50 .

The last theoretical savings can be calculated lowering the power when over 4,6kW. For 28 families, after revision of the energy bills to lower energy capacity to $3,45 \mathrm{~kW}$, the estimated savings range from $37 €$ to more than $135 €$, averaging $72 € /$ year for those 28 contracts.

To sum up, the average maximum achievable savings are up to a $37 \%$ (231 €/year; regulated tariff, plus social tariff, plus time-of-use tariff with $50 \%$ consumption at valley, plus power capacity $3,45 \mathrm{~kW}$ or lower). For the six worst contracts, the savings are more than the $50 \%$ (one of them saving $600 € /$ year). Unexpectedly, two energy bills were even lower than the theoretical optimal electricity bill, as they were using the ToU tariff with a better balance than the assumption of $50 \%$ during peak hours.

\section{USURBIL}

The same procedure was followed with the 6 contracts provided by the municipality of Usurbil.

4 contracts could benefit from the regulated tariff, saving on average around $106 € /$ year, the $14 \%$ of the total amount of money used for AES by the Council of Usurbil. If the 5 contracts without the social tariff were eligible for it, the calculated average savings would be $117 € /$ year. These 5 cases can realise savings ranging from $25 \%$ to $45 \%$, with an average of $33 \%$. The average additional savings for the 5 contracts not using the ToU tariff are more than $32 € /$ year. The contracted power capacity was revised for one case, saving $45 € /$ year. In the end, average savings are up to $40 \%$ (199 €/year), ranging from an $8 \%$ to more than $49 \%$ (up to $407 € /$ year). A summary of the results of the analysis of the energy bills for both municipalities is displayed in Table 4.

\section{Table 4}

Data on beneficiaries being assisted by the municipal social services of Zarautz and Usurbil

\begin{tabular}{|c|c|c|c|c|c|c|c|c|c|c|}
\hline & \multicolumn{2}{|c|}{$\begin{array}{c}\text { Switching } \\
\text { to regulated tariff }\end{array}$} & \multirow{2}{*}{$\begin{array}{c}\text { Realized } \\
\text { savings } \\
\text { from } \\
\text { total }\end{array}$} & \multicolumn{2}{|c|}{$\begin{array}{c}\text { Switching } \\
\text { to social tariff }\end{array}$} & \multicolumn{2}{|c|}{$\begin{array}{l}\text { Switching } \\
\text { to ToU tariff }\end{array}$} & \multicolumn{2}{|c|}{$\begin{array}{c}\text { Lower } \\
\text { the power capacity }\end{array}$} & \multirow{2}{*}{$\begin{array}{c}\text { Possible } \\
\text { savings } \\
\text { from } \\
\text { total }\end{array}$} \\
\hline & $\begin{array}{l}\text { Revisable } \\
\text { contracts }\end{array}$ & $\begin{array}{c}\text { Avg. } \\
\text { savings }\end{array}$ & & $\begin{array}{l}\text { Revisable } \\
\text { contracts }\end{array}$ & $\begin{array}{c}\text { Avg. } \\
\text { savings }\end{array}$ & $\begin{array}{l}\text { Revisable } \\
\text { contracts }\end{array}$ & $\begin{array}{c}\text { Avg. } \\
\text { savings }\end{array}$ & $\begin{array}{l}\text { Revisable } \\
\text { contracts }\end{array}$ & $\begin{array}{c}\text { Avg. } \\
\text { savings }\end{array}$ & \\
\hline Zarautz & 30 & $\begin{array}{c}108 \\
€ / \text { year }\end{array}$ & $9 \%$ & 44 & $\begin{array}{c}130 \\
€ / \text { year }\end{array}$ & 50 & $\begin{array}{c}134 \\
€ / \text { year }\end{array}$ & 28 & $\begin{array}{c}72 \\
€ / \text { year }\end{array}$ & $37 \%$ \\
\hline Usurbil & 4 & $\begin{array}{c}106 \\
€ / \text { year }\end{array}$ & $14 \%$ & 5 & $\begin{array}{c}117 \\
€ / \text { year }\end{array}$ & 5 & $\begin{array}{c}32 \\
€ / \text { year }\end{array}$ & 1 & $\begin{array}{c}45 \\
€ / \text { year }\end{array}$ & $40 \%$ \\
\hline
\end{tabular}




\section{Discussion of the results and further improvement thanks to smart grids}

The first thing to outline from the data analysed is that the heterogeneity of the cases is a problem, in terms of consumption or type of contract, as the available variables to analyse each case are limited and the studied population is not enough for statistical purposes.

The low number of social tariffs contracted is worth stressing. According to the National Commission on Markets and Competition (Comisión Nacional de los Mercados y la Competencia, CNMC), only half of consumers knew of the existence of the social tariff, and $60 \%$ of them were aware of the requirements needed to benefit from it (CNMC, 2017). But a Spanish survey focusing on aged people and people with disabilities, i.e. two of the populations considered as vulnerable (Steve Pye and Audrey Dobbins, 2015), established that 33\% of them do not know what the social tariff is, and $28 \%$ do not know the procedure or whether they could benefit from it (HISPACOOP, 2017). So, the social tariff is not an issue of general concern for Spanish consumers, including the vulnerable.

The low usage ToU tariff is also to be noted. Apart from the lack of knowledge on it, ToU pricing is complex, as vulnerable consumers and others are not able to access new (digital) services and products because investment in new systems is needed to take advantage of it (Simshauser et al., 2011). In rural Scotland, consumers could cut their electricity bills by a third by switching from Standard Variable Tariffs (The Scottish Government, 2016), including most of those with ToU meters.

However, Simshauser, Nelson, and Doan (2011) measured that $64 \%$ of the households that declare that they contract a ToU take into account electricity prices in the different sections of the day in their consumption habits. This is also the case of families in Zarautz, who overall made a really good use of ToU pricing.

Although the population of study in both municipalities is very dissimilar, the achievable savings is more or less the same (Table 4). Around a $10 \%$ of savings can be realised by switching to the regulated tariff, and this is always possible if the contract is in the open market. Utilities offer discounts in some terms in the open market, but more expensive prices in others, and include 'extra' services some times. Explicit withdrawal must be requested to avoid 'extra' services; although they are supposed to have problems paying the bills, 8 contracts in Zarautz and 2 in Usurbil have extra charges. The average savings from the withdrawal of 'extra' useless services is more than $30 € /$ year. In the end, although the Spanish electricity market was liberalised, still the regulated tariffs are the lowest ones compared to open market tariffs. 
A maximum achievable percentage of savings was calculated, not far from $40 \%$ for both cases. As stated before, those are theoretical savings, as all the consumers cannot benefit from all the tariffs excepting the regulated one.

After the workshops in energy advice with the low-income households designated by the social services, few contracts were changed. On the one hand, not all the recipients of the AES went to the call. And on the other hand, although all the needed information was provided, some of those attending didn't go to the utility company to optimise their contracts after the workshop. All procedures can be done at the same time when going to the utility to ask for a regulated tariff and apply for the social tariff if you are entitled to it.

This opens a question concerning increasing the rate of families improving the conditions of their contracts: "In the switching tariff process, if institutional / administrative barriers and information barriers are removed, why are some of the households still reluctant to change their contracts?", and then, "Can we try new ways of convincing low-income households to tariff switching?" In the end, how can we elicit a change of behaviour of the so-called non-switchers, those households reluctant to optimise the conditions of the contracts?

Factors affecting switching include inadequate information, lack of participation, hassle, financial constraints such as arrears or prepayment meters (Lorenc et al., 2013), risk aversion and a need to retain budgeting control, and digital exclusion (Sara Davies et al., 2016). Low-income households are reluctant to change supplier and/or tariff, and tariff switching has been shown to have limited success with them. In the end, cross relationships can be described; older people display a lack of interest in change, loyalty to existing supplier, rarely are active consumers and cite previous negative experiences or having difficulties using websites (Lorenc et al., 2013). Also, it was confirmed that being a tenant is a barrier in Zarautz and Usurbil, as their landlords do not allow changing the electricity contract ownership.

In Scotland, a weak response by most electricity consumers, particularly those with electric heating, to "switching" supplier which could save them a third or more on their very high bills was observed. The recommendations were encouraging and supporting customers to switch tariff and supplier to achieve big reductions in their electricity bills (The Scottish Government, 2016).

The intervention can be further improved if the advice is much more personalised, and contracts can be further fine-tuned through information on the low-income households: type of family (number of person living there, if the people are aged, if they have children, if any person with 
disabilities, if unemployed..), type of housing (single-family, terraced house, farmhouse, 1 st floor, last floor, year of construction) and if the heating is electric, gas or only electric, etc. So, it should be possible to characterise the household, and advice most appropriate electricity tariff. This implies a closer relationship with the social services, and this means the intervention becomes more time and money consuming.

The improvements of the intervention can be simplified thanks to smart grids. In order to give better-targeted advice during the home visit, remote access to an existing period of the client's energy data could be provided in advance (Fischer et al., 2014). Additionally, instead of the assumption of lowering to $3,45 \mathrm{~kW}$, it is possible to calculate the best power capacity to be contracted. Online access to data from Spanish smart meters is available thanks to the electricity utility, where an option displays the monthly power demand maximums for each year. Hourly data can be obtained from the web as well, and can be used to advise the ToU. The assumption of consuming 50\% of the electricity during valley hours can be adjusted, although better use of ToU can be achieved through training. Ideally, systems as electric heaters for storing sanitary hot water are needed to take advantage of the ToU, but as previously mentioned, it can be a barrier for low-income households.

\section{Conclusions}

Social financial assistance to households in fuel poverty situation raise important questions as it is based on public budgets. From this also emerges an important point further consideration, namely should financial interventions be more efficient? Most tax payers prefer a lower public budget, although paying more taxes could be understandable to some if this means that vulnerable populations are assisted. If we put our eyes on the low-income households, the most efficient behaviour possible should be expected. But at the same time, our analysis confirmed that extra charges are found in the energy bills of a not insignificant number of low-income households. Some utility providers are not offering the best energy price for families assisted by the social services, i.e. more public resources are needed for a given population. The Spanish National Commission on Markets and Competition fined two utilities for failing to comply with the requirements for contracting with its clients (CNMC, 2019). The role of the regulator is also questioned; in 2008 Ofgem began a series of regulatory interventions after being open to competition for residential customers, and in 2016 the Competition and Market Authority found that some were inappropriate (Littlechild, 2019). As 
for the authors, there should be a balance between the right to private profits and the right to access to energy services of the vulnerable. For example, consumers should be made eligible for discounts in energy bills automatically and/or be offered an auto-switch scheme (Scott Corfe and Nigel Keohane, 2018).

In this article, we described two types of innovation that can draw some clues to address this issue. First, energy cooperatives, new actors in the energy market for producing and commercializing renewable energy, and this is more important than having a cheaper price (Hoppe and Coenen, 2016). Members of these cooperatives save more energy than people who are not member of a cooperative (Akadiadis et al., 2017), an average reduction of $50 \%$ of their consumption was observed after installing photovoltaic cells.

The members of energy cooperatives do not limit themselves to renewables or energy efficiency. An inventory and analysis of practices of members of REScoop, a network of energy cooperatives, showed that price transparency is one of the most valued services (Hoppe and Coenen, 2016). A survey among the members of energy cooperatives in Spain, carried out to know their preferences in relationship with the social tariff, concluded that members were in favour of investing a part of the profits in fighting against the problem of energy poverty (Gabiola et al., 2016). Energy cooperatives can increase the production of sustainable, renewable energy as well as improving access to energy (ILO, 2013). The French energy cooperative Enercoop has an ongoing project based on microdonation scheme, whereby members of cooperative donate smalls amounts of money (Antepara and Claeyé, 2016).

Here, the case of an energy cooperative in the North of Spain, GoiEner, is studied. GoiEner does not manage contracts of families in a situation of fuel poverty as they cannot offer the social tariff, but they were engaged in a collaboration with the social services of two municipalities in order to help low-income hourseholds in tariff switching. After revising the energy bills, workshops in energy advice are organised aiming to build an autonomous dynamic at the social services. One of the main findings of our study is that savings between 10 and $40 \%$ are achievable. Unexpectedly, savings expected after the energy advice are not realised by the concerned households.

The second innovation is connected to new technologies. As data from smart meters can be reached via the internet, opportunities for social innovation appear to be feasible. Every consumer will also be entitled to a smart meter equipped with common minimum functionalities (European Commission, 2016). It is envisaged that the primary role of new 'smart tariffs' would be to manage peak demand through such mechanisms as 
ToU tariffs, critical peak pricing, load control, maximum demand and real-time pricing to encourage load shifting (National Right to Fuel Campaign, 2011).

In France, as in other MS, smart grids will affect many aspects of the energy market. The unit costs of a certain number of services carried out by ENEDIS (formerly ERDF, the Power Grid Operator in France) are determined by the French Commission for the regulation of energy (Commission de régulation de l'énergie, CRE). These services, which are currently mainly travel and labour costs and previously involved one or more journeys, will be largely avoided once the smart meters have been deployed. Among these benefits, the cost of a number of services will be close to zero, including (RAPPEL, 2016):

- To lower / increase the subscribed power,

- Restore the service after a cut-off due to unpaid bills (if requested within 15 hours, this can be done the same day thanks to teleoperation, and not systematically the day after).

- For beneficiaries of social tariffs, the energy transition law of August 2015 states that "the availability of data from smart meters permit to transmit consumption data and an offer attached, expressed in euro, by means of a remote device, displayed in real time and at no cost." (Government of France, 2015)

However, the Court of Auditors points to an information deficit and too high costs for the consumer, and criticizes the generous financial conditions granted to ENEDIS (Dominique Pialot, 2018).

Smarts meters are in the first stages of development for the natural gas grid, but the idea is to install them in the same way as in the electricity network. So, similar advantages can be drawn.

Energy cooperatives have already adopted smart meters (Akadiadis et al., 2017). The intervention can be improved with more information from the households, so that GoiEner can arrange a new support action based on data analysis, even though the families under analysis do not have a contract with this energy cooperative. If so, the best power capacity can be advised or the use of the ToU tariff optimised.

Technologies like solar PV panels, energy storage systems, and smart home devices might have the potential for major positive changes, creating a more efficient, low carbon, and equitable system for all consumers. However, without bold regulatory action, this impact could be destructive, creating a power system that works for certain customer strata at the expense of others (Burger et al., 2019).

Some more proposals can be anticipated, as regulating alternatives to the cut-offs, which is sometimes even more important than financial 
or other types of interventions. Steve Pye and Audrey Dobbins (2015) described two examples:

1. In Italy, the presence of smart meters may allow the policy makers to reconsider the design of the measures in order to guarantee a "minimum level of consumption" (compatible with the welfare requirements) to all the households.

2. In Germany, households not able to pay their bills had their power demand reduced to $1,000 \mathrm{~W}$ instead of being completely cut-off from electricity so that a basic energy amount could still be drawn. This only occurred after households had received three warnings.

These two examples could be alternatives to cut-offs, which can avoid the accumulation of debts, and the compulsory paying of additional reconnection charges, and subsequent building up of debts. But we can think not only of alternatives to cut-offs, but also of "smart tariffs". Prepayment is envisaged by several entities in the same way that they pay for phone credit, or combined with an in-home display (IHD) (Simpson et al., 2016). This all is not without problems, as a consequence of tight household budgets and the need for savings, households will not always top up their meters (and in doing so self-disconnect) (Steve Pye and Audrey Dobbins, 2015). Low-income households, who are the typical consumers of pre-paid metered electricity, have few opportunities to actually reduce their consumption. Thus, this scheme eventually leads to a higher risk of 'self-disconnecting' (e.g., running out of credit), resulting in no electricity, which may subsequently lead to potential serious health implications (O'Sullivan et al., 2015). Periods of selfdisconnection won't be a solution to unexpected debts, as the standing charge will come back if reconnection is considered (npower, 2010). MS regulators should move to mandate suppliers to offer the same deals to prepayment consumers as they do to other consumers (Scott Corfe and Nigel Keohane, 2018).

Finally, the new concept of peer-to-peer electricity sharing, which creates a marketplace for electricity, is possible thanks to smart meters. In this marketplace, the people who can afford power generating sources, such as solar panels, can sell electricity to people requiring more electricity at certain times, but also to people who are unable to afford generating sources. These adhoc micro-grids created by sharing of resources can be a way to providing affordable electricity to all (Inam et al., 2015). 
FIGHTING AGAINST FUEL POVERTY BY COLLABORATING WITH SOCIAL SERVICES...

\section{Acknowledgements}

This paper is a revised and expanded version of a paper entitled "Collaboration with social services to analyse data from energy bills and advice best electricity tariffs of designated households" presented at Advances in fuel poverty research and practice II, September 2017, Nottingham (UK).

\section{References}

ACER (2016) ACER Market Monitoring Report 2015 - ELECTRICITY AND GAS RETAIL MARKETS. November. Agency for the Cooperation of Energy Regulators and the Council of European Energy Regulators. Available at: https://www.acer.europa.eu/Official_documents/Acts_of_the_Agency/ Publication/ACER\%20Market\%20Monitoring\%20Report\%202015\%20\%20ELECTRICITY\%20AND\%20GAS\%20RETAIL\%20MARKETS.pdf

Akadiadis C, Savvakis N, Mamakos M et al. (2017) Analyzing Statistically the Energy Consumption and Production Patterns of European REScoop Members. Results from the H2020 Project REScoop Plus.

Antepara I and Claeyé F (2016) Examples of Social Business effectively addressing Fuel Poverty by overcoming the barriers when implementing Energy Efficiency measures. In: Social Business Academia Conference, Paris, November 2016.

Association for the Conservation of Energy (2013) Energy efficiency and excess winter deaths: Comparing the UK and Sweden. Briefing, November. Available at: http://www.energybillrevolution.org/wp-content/uploads/2013/12/ACEResearch-Comparing-the-UK-and-Sweden-3.12.13.pdf

Bouzarovski S (2017) Energy Poverty:(Dis) Assembling Europe's Infrastructural Divide. Springer.

Burger S, Schneider I, Botterud A et al. (2019) Chapter 8 - Fair, Equitable, and Efficient Tariffs in the Presence of Distributed Energy Resources. In: Sioshansi F (ed.) Consumer, Prosumer, Prosumager. Academic Press, pp. 155-188. DOI: 10.1016/B978-0-12-816835-6.00008-5.

CNMC (2015) Spanish energy regulator's national report to the European Commission 2015. 23 July. Comisión Nacional de los Mercados y la Competencia (CNMC). Available at: https://www.ceer.eu/ eer_publications/national_reports/national_reporting_2015/-/ document_library_display/35oiTkPsE0q7/view_file/3737587?_110_ INSTANCE_35oiTkPsE0q7_redirect=https\%3A\%2F\%2Fwww.ceer. eu\%2Feer_publications\%2Fnational_reports\%2Fnational_reporting $2015 \% 3 \mathrm{Fp}$ _p_id\%3D110_INSTANCE_35oiTkPsE0q7\%26p_p_ lifecycle\%3D0\%26p_p_state\%3Dnormal\%26p_p_mode\%3Dview\%26p_p_ col_id\%3Dcolumn-1\%26p_p_col_pos\%3D8\%26p_p_col_count\%3D10 
CNMC (2017) Boletín de indicadores eléctricos de octubre de 2017. Boletín de indicadores eléctricos, 31 October. Comisión Nacional de los Mercados y la Competencia (CNMC). Available at: https://www.cnmc.es/sites/default/ files/1836153_0.pdf.

CNMC (2019) La CNMC multa a Iberdrola Clientes y EDP Energía por incumplir los requisitos de contratación con sus clientes. Available at: https://www.cnmc.es/sites/default/files/editor_contenidos/Notas\%20de\%20 prensa/2019/20190221_NP_Sancionador_EDP_Iberdrola_183-17_48-18. pdf

Crampes C and Waddams C (2017) Empowering electricity consumers in retail and wholesale markets. 9 March. Centre on Regulation in Europe (CERRE. Available at: http://www.cerre.eu/sites/cerre/files/170309_CERRE_ EnergyConsumers_Final.pdf

Devalière I and Bernard C-A (2016) Les chiffres-clés de la précarité énergétique. Les études de l'ONPE 2, November. Paris: ONPE. Available at: http://onpe.org/ sites/default/files/pdf/tableau_de_bord/chiffres-cles-precarite-energetiquenovembre2016.pdf.

Dominique Pialot (2018) Le compteur Linky ne tient pas ses promesses. Available at: https://www.latribune.fr/entreprises-finance/industrie/energieenvironnement/le-compteur-linky-ne-tient-pas-ses-promesses-767572.html

European Commission (2016) New electricity market design: a fair deal for consumers. 30 November. European Commission. Available at: https:// ec.europa.eu/energy/sites/ener/files/documents/technical_memo_ marketsconsumers.pdf

EUSTAT (2016) La población de la C.A. de Euskadi pierde 1.324 personas en 2016. Available at: http://www.eustat.eus/elementos/ele0013700/not0013710_c.html

Fischer JE, Costanza E, Ramchurn SD et al. (2014) Energy Advisors at Work: Charity Work Practices to Support People in Fuel Poverty. In: Proceedings of the 2014 ACM International Joint Conference on Pervasive and Ubiquitous Computing, New York, NY, USA, 2014, pp. 447-458. UbiComp '14. ACM. DOI: $10.1145 / 2632048.2636081$.

Gabiola EJ, Gázquez JDP and Rodríguez JAS (2016) EL BONO SOCIAL Y LAS COOPERATIVAS ENERGÉTICAS VERDES: SITUACIÓN Y PERSPECTIVAS 1/THE SPANISH SOCIAL TARIFF AND RENEWABLE ENERGY COOPERATIVES: SITUATION AND PERSPECTIVES. REVESCO: Revista de Estudios Cooperativos (122): 1.

Government of France (2015) Mieux rénover les bâtiments pour économiser l'énergie, faire baisser les factures et créer des emplois. LOI n.o 2015-992 du 17 août 2015 relative à la transition énergétique pour la croissance verte. Available at: https://www.legifrance.gouv.fr/affichTexteArticle.do?idArticle=JORFARTI 000031044572\&cidTexte=LEGITEXT000031047847\&categorieLien=id

HISPACOOP (2017) Estudio sobre los consumidores vulnerables en el sector eléctrico. Madrid: Confederación Española de Cooperativas de Consumidores y Usuarios (HISPACOOP). 
Hoppe T and Coenen F (2016) Exploring Interventions and Tools Used by REScoops to Lower Householders' Energy Consumption and Stimulate Investment in RES Projects.

IDAE (2016) Informe de precios energéticos regulados. Datos enero de 2016. IDAE. Available at: http://www.idae.es/uploads/documentos/documentos_ Tarifas_Reguladas_ene_2016_a197c904.pdf

ILO (2013) Providing clean energy and energy access through cooperatives. International Labour Office, Cooperatives Unit, Green Jobs Programme. Available at: http://www.ilo.org/wcmsp5/groups/public/---ed_emp/---emp_ ent/documents/publication/wcms_233199.pdf

Inam W, Strawser D, Afridi KK et al. (2015) Architecture and system analysis of microgrids with peer-to-peer electricity sharing to create a marketplace which enables energy access. In: 2015 9th International Conference on Power Electronics and ECCE Asia (ICPE-ECCE Asia), June 2015, pp. 464-469. DOI: 10.1109/ICPE.2015.7167826.

Jeffrey Hardy (2015) Non-traditional business models: Supporting transformative change in the energy market. Ofgem discussion paper.

Kirk J (2017) The work of Robin Hood Energy. In: Advances in fuel poverty research and practice II, Nottingham, September 2017.

Lanbide (2016) Beneficiarios de Renta de Garantia de Ingresos por Territorios Historicos durante el 2016. Available at: http://www.lanbide.euskadi.eus/ general/-/estadistica/beneficiarios-de-renta-de-garantia-de-ingresos-porterritorios-historicos-durante-el-2016/.

Littlechild S (2019) Promoting competition and protecting customers? Regulation of the GB retail energy market 2008-2016. Journal of Regulatory Economics 55(2): 107-139. DOI: 10.1007/s11149-019-09381-0.

Lorenc A, Pedro L, Badesha B et al., (2013) Tackling fuel poverty through facilitating energy tariff switching: a participatory action research study in vulnerable groups. Public Health 127(10): 894-901. DOI: http://dx.doi. org/10.1016/j.puhe.2013.07.004.

Martiskainen M, Heiskanen E and Speciale G (2018) Community energy initiatives to alleviate fuel poverty: the material politics of Energy Cafés. Local Environment 23(1): 20-35. DOI: 10.1080/13549839.2017.1382459

Mengolini A and Vasiljevska J (2013) The social dimension of smart grids. Scientific and Technical Research series. Luxembourg: European Commission, Joint Research Centre - Institute for Energy and Transport. Available at: https:// ses.jrc.ec.europa.eu/sites/ses.jrc.ec.europa.eu/files/publications/the_social_ dimension_of_smart_grids.pdf

National Right to Fuel Campaign (2011) Smart meters? Will smart meters help the fuel poor? December. National Right to Fuel Campaign. Available at: http:// www.right2fueluk.com/downloads/NRFCsmartmeterreport.pdf

npower (2010) I have a prepayment meter, why do I pay standing charge? Available at: https://customerservices.npower.com/app/answers/detail/a $\mathrm{id} / 354 /$ / i-have-a-prepayment-meter $\% 2 \mathrm{C}$-why-do-i-pay-standing-charge $\% 3 \mathrm{~F}$ 
One Corby Policy Committee (2016) Council Support of Energy Switch Scheme. Open Decision Item, 29 November. One Corby Policy Committee.

Ooms M, Bijnsdorp S, Huygen A et al., (2016) Social innovation in energy supply: case study results. D7.3, December. TNO. Available at: https://www.si-drive. eu/wp-content/uploads/2017/03/SI-DRIVE-Deliverable-D7_3-Energy-1.pdf

O'Sullivan KC, Howden-Chapman PL and Fougere GM (2015) Fuel poverty, policy, and equity in New Zealand: The promise of prepayment metering. Energy Research \& Social Science 7(Supplement C): 99-107. DOI: https://doi. org/10.1016/j.erss.2015.03.008

RAPPEL (2016) Compteurs communicants d'électricité (Linky). Available at: https://www.precarite-energie.org/Lcompteurs-communicants-d.html.

Red Eléctrica Española (2017) Lumios. Available at: https://www.esios.ree.es/es/lumios

Sara Davies, Andrea Finney and Yvette Hartfree (2016) Paying to be poor: uncovering the scale and nature of the poverty premium. November. University of Bristol. Available at: http://www.bristol.ac.uk/media-library/sites/geography/ $\mathrm{pfrc} / \mathrm{pfrc1615}$-poverty-premium-report.pdf

Scarpellini S, Hernández MAS, Llera-Sastresa E et al. (2017) The mediating role of social workers in the implementation of regional policies targeting energy poverty. Energy Policy 106: 367-375. DOI: https://doi.org/10.1016/j. enpol.2017.03.068

Scott Corfe and Nigel Keohane (2018) Eliminating the poverty premium in energy. April. The Social Market Foundation. Available at: http://www.smf.co.uk/wpcontent/uploads/2018/04/Eliminating-the-poverty-premium-in-energy.pdf

Simpson K, Smith K and Thomas K (2016) Smart prepayment meters: Householder experiences. March. Centre for Sustainable Energy. Available at: https://www. cse.org.uk/downloads/file/smart-prepay-hh-experiences-report-march16.pdf

Simshauser P, Nelson T and Doan T (2011) The Boomerang Paradox, Part II: Policy Prescriptions for Reducing Fuel Poverty in Australia. The Electricity Journal 24(2): 63-75. DOI: https://doi.org/10.1016/j.tej.2011.01.017

Spanish Gov. (2015) Conceptos por los que pago en mi factura de electricidad. Available at: http://www.controlastuenergia.gob.es/factura-electrica/factura/ Paginas/conceptos-factura.aspx

Steve Pye and Audrey Dobbins (2015) Energy poverty and vulnerable consumers in the energy sector across the EU: analysis of policies and measures. Policy 2. Available at: http://ec.europa.eu/energy/en/studies/energy-poverty-andvulnerable-consumers-energy-sector-across-eu-analysis-policies-and

The Scottish Government (2016) An action plan to deliver affordable warmth in rural Scotland. October. The Scottish Government. Available at: http://www. gov.scot/Resource/0050/00508120.pdf

Thomson H, Snell CJ and Liddell C (2016) Fuel poverty in the European Union: a concept in need of definition? People, Place \& Policy Online 10(1): 5-24. DOI: $10.3351 / \mathrm{ppp} .0010 .0001 .0002$

Tirado S and Jiménez Meneses L (2016) Energy poverty, crisis and austerity in Spain. People, Place and Policy 10(1): 42-56. 